\title{
Foreign Megastores and the Nigerian Economy: A Study of Shoprite
}

\author{
Chidozie, Felix Chidozie \\ Department of Political Science and International Relations, \\ College of Development Studies, School of Social Sciences, Covenant University \\ Felix.chidozie@covenantuniversity.edu.ng, Felix.chidoziefoundation@gmail.com (08033815520) \\ Olanrewaju Ilemobola Peter \\ Department of Political Science and International Relations, \\ College of Development Studies, School of Social Sciences, Covenant University \\ Peter.ojo@covenantuniversity.edu.ng (08034620080) \\ Akande, Omowunmi Omotoyese \\ Graduate of Department of Political Science and International Relations, \\ College of Development Studies, School of Social Sciences, Covenant University \\ Nikah_wunmi@yahoo.com (07063140639)
}

\section{Doi:10.5901/mjss.2014.v5n1p425}

\section{Abstract}

This paper examines the phenomenon of foreign megastores in Nigeria. It offers a historical analysis of the factors responsible for their presence, emerging trends engendered by foreign megastores within the Nigerian market and the implications of such presence for the Nigerian economy. It demonstrates that foreign megastores have profoundly affected the economy and social environment within Nigeria. It adopts as a model of analysis the South African retail store, Shoprite and observes how it is progressively influencing consumer behaviour, expanding the influence of retailers and directing financial flows into Nigeria. Among other things, Shoprite offers consumers the luxury of spacious well organized parking lots, clean environments, a friendly staff and competitive prices to mention a few. Observers of the rapid expansion of Shoprite agree that its presence in Nigeria means that roadside sellers of bread, vegetables and meat would be adversely affected in a country where retailing is largely informal; it thus threatens existing market structures. It also significantly contributes to the fast rising level of health challenges in Nigeria. To this effect, the study set out to test the impact of Shoprite as a foreign megastore on Nigeria's economy and the data obtained through interviews and from the distribution of questionnaires, and analyzed with the aid of the Statistics Package for Social Science (SPSS), reveal that for Nigerian citizens, the positive effects outweigh the negative and that though foreign megastores are influencing market patterns, they cannot completely displace traditional market systems in Nigeria, at least not in this century; they however, can modify them. More specifically, findings revealed that Shoprite has boosted the Nigerian economy and has significantly shaped the pattern of internationalization of retailing in Nigeria. The research thus recommends, among other things, that government should through the appropriate agencies ensure that it monitors the activities of foreign megastores so as to prevent them from monopolizing the markets and dictating prices. It should also seek out means of ensuring that Nigerians in South Africa have a level playing field and opportunities for expansion like their South African counterparts in the former.

Keywords: Foreign Megastores, Nigerian Economy, Shoprite, South Africa.

\section{Introduction}

The world has, at unimaginable speed evolved in the past five decades, creating an intricate web of relationships among states and individuals alike. This situation has been referred to as globalization, a phenomenon in which economics, politics, culture, business and technology have become inextricably interwoven (Agbu, 2004; Conversi, 2010; Movius, 2010; Omotola, 2010). The factors responsible for the emerging trend of globalization are countless. Indeed, demands for new approaches to managing insecurity, for new breakthroughs in peacekeeping, for more creative approaches in second-generation peacekeeping activities, for addressing the new security issues of environmental degradation and protection of human rights, and for more effective programs to promote sustainable development tests the capacity of 
states (Mingst 1999: 2). Such dynamics facilitated by liberal principles that encourage free trade, open markets with limited governmental interference and the uninhibited pursuit and accumulation of wealth have necessitated cooperation, while increasing interdependence among the numerous actors in the international system creating a system sustained by individuals, states and most importantly in contemporary times, international institutions and multinational corporations.

Multinational Corporations (MNCs) play a complex and controversial role in the global political economy. While most multinationals are engaged principally in the production and sale of goods and management of finances (.i.e. banks and other financial institutions), others sell services. Moreover, it has been contended that; "more down-to-earth service businesses such as retail grocery stores can also become multinational corporations" (Goldstein and Pevehouse 2011: 340). As Salmon and Imber (2008) put it,

\begin{abstract}
"Multinational corporations have become at least as important as states in the international political economy, the financial turnover of many twenty-first-century multinational corporations exceeds that of the GDP of a substantial number of states and consequently many states have become supplicants in endeavoring to attract multinationals to establish links with them. The state no longer regulates the supply and cost of capital or provides the regulatory regime in which it is supplied. It is not only the manufacturing companies that have become global in their operations, so too have the companies that supply them with services. Local banks survive only as a consequence of protectionism, as in the USA, or by virtue of having a high degree of specialization, usually in catering for the needs of clients with very high net wealth. Indeed, banks have been forced to become multinational corporations in order to keep pace with their clients. Manufacturing companies now manufacture very close to their markets, or where labor, raw materials, taxation or production costs are lowest. Developments in logistics, especially in sea and airfreight, have also contributed to the transfer of power from the state to the private sector. Investment banks, offshore funds and private equity may be glamorous, but super container ships, supertankers and 747 freighters have played an equally pivotal role" (Salmon and Imber 2008: 69).
\end{abstract}

This simply means that MNCs (which are mainly Western companies) have become instruments for furthering global interdependence or dependence as some would argue and have as their major targets Third world countries where there are large markets, cheap labor and a vital need of financial flow in the form of foreign direct investment (FDI), of which Nigeria is one. It is also interesting to note that the category of multinational corporations which this study focuses on is new to political-economic studies in Africa as it reveals the critical and emerging issue, indeed, nagging question of prospects in modern imperialism of Africa by Africans, in this case, Nigeria and South Africa, in view of their shared history of Western domination and struggles for independence.

The Nigerian economy, since independence has recorded significant levels of progress especially in the oil and telecommunication sectors of the economy. Adeolu Ayanwole however, argues that "notwithstanding these positive developments, the Nigerian economy remains confronted by many serious challenges" (Adeolu Ayanwole, 2007: 11), of which rising inflation rates, unemployment, fluctuating currency rates, poor infrastructural facilities, widespread insecurity, low standards of living and growing poverty and illiteracy levels pose some of the most crucial problems that confront citizens, businessmen and policy makers in the country.

In recent years however, the Nigerian market has evolved as a response to capitalist-globalization and has witnessed the emergence and intensification of organized retail outlets (i.e. supermarkets), most of which are foreign and private-owned, as opposed to the traditional open markets which have dominated the Nigerian market throughout all of its history. Although this novel situation has its advantages, there are also possible devastating socio-economic consequences for the country.

In view of this background, the paper is divided into five parts. Following the introduction is the literature review on the subject matter. The third section discusses the history of foreign megastores in Nigeria and the fourth section presents and analyzes data on Shoprite and the Nigerian economy. The final section concludes the work and offers relevant suggestions.

\title{
2. Literature Review
}

It is important to begin this discourse by noting that one of the most glaring consequences of globalization has been the increased participation of non-state actors in the form of MNCs in the international system; their activities impacting both individuals and countries.

Similarly, Theodis Perry (2001:3) observes that cities, towns and rural areas have changed dramatically over the past decade, and that the proliferation of discount, general merchandise stores such as Target, Wal-Mart and Kmart has had a significant impact on the world's urban and rural landscapes, affecting the way we shop, live, work and play, all 
evidences of globalization. Put differently, "it is the economic activities of multinational corporations (MNCs) that promote globalization" (Oyadiran and Akintola, 2003: 1).

For instance, Vincent Onodugo (2012:68) argues that Nigeria has played host to MNCs long before independence till date whose numbers and activities have grown over time as the country struggles to develop socio-economically as a nation. He however, adds that "after over fifty years of nationhood, the economic growth trajectory of Nigeria is at best chequered in spite of the growing presence of these MNC in its core sectors of oil, banking and manufacturing sectors. Likewise, Begg, Fischer and Dornbusch (2008:8) also contend that "these multinational corporations sometimes seem to have become more powerful than governments".

According to Loto (2011:160), "the integration of individual economies into the world economy, has progressed, of which Nigeria, since 1986 has gradually been integrating with the global economy, forming new links between developed and developing economies", and even among developing countries as exemplified by its economic and diplomatic relations with South Africa in this case.

Hence, the issue of foreign economic presence within the Nigerian market and the societal implications of such phenomenon for Nigeria have become central to socio-political and economic studies and have been subject to debates and reviews between and among Western and African scholars, researchers and institutions alike, all with varying and sometimes similar assumptions and conclusions.

On this note, Oyadiran and Akintola (2003:1) agree that globalization, multinational corporations and direct foreign investment are triangular phenomena in international economic relations which shape economic relations among states of the world, and that although globalization is the driving force, it cannot work in isolation.

On the other hand, Bakare (2010) contend that the activities of multinational corporation is beneficial to recipient nations in that it necessitates the inflow of foreign exchange and new technologies, generates employment, infuse labour and marketing skills and enhance the income of the recipient countries through taxation and payment of royalties. Specifically, he argued that "multinational corporation investment have contributed positively to the growth of Nigerian economy" (Bakare, 2010: 172).

In addition, retailers are critical economic agents who help to create demand because of their affinity with both the consumers and producers. In fact, retail sales are an important economic indicator because consumer spending drives much of the economy (Manufacturers Today Report, 2013). This is validated by Business and Economy (2012:12) which affirms that "foreign investment in the Nigerian retail market has reached an all-time high, attracting about \$US1.3billion (about N208 billion) in the last two years, owing to rising purchasing power and huge potential of the nation's economy ".

On the contrary, Oyadiran and Akintola (2003) argue that Third World countries bear the brunt, instead of gaining in the process; they lose in a system where MNCs are making direct foreign investment to benefit just themselves but not the peripheral sphere of the globe where the Third World countries belong. Foreign domination in specific sectors is very evident in Nigeria and all across Africa. Mukema Wa Ngugi (2011:14) maintains the view that "we are driving ourselves out of business and further into dependence". Oyadiran and Akintola (2003:1), therefore recommend "that for the Third World to benefit immensely from globalization, it needs strong governments, through which the positive aspects of globalization can be actualized". Onwuka and Eguavoen (2007:50) also agree that the Nigerian government can benefit from this experience if the country pursues development within the context of globalization.

Accordingly, Ayandiji Aina (2006:4), points out another disadvantage of multinational corporations within the context of globalization. He argues that evidently, globalization has brought about the domination of the Nigerian economy since its basic export is woven around raw materials. He stressed that the raw materials provide basis for production and further production; whereas export in Nigeria promotes economic diversification abroad, and restricts diversification in the domestic setting. He concluded that, the Nigerian economy is thus not competitive in the global trade circle. Indeed, Bakare (2010:172) in a similar vein argues that, the "MNCs relate to the African economies mainly as their sources of raw materials and market for their manufactured goods".

Viewing the phenomenon of the MNCs from the Western lens, Lyman Sargent (2006:43) argues that one positive result of globalization from the view of the third World workers, is that corporate codes of behaviour developed within the First World have sometimes, usually because of protests within the First World, been applied in the Third World to help oppressed workers there. The best known example being the international campaign against the wages and working conditions found in Third World supplier to Nike. Also, protests and boycotts in North America and Europe helped change conditions in Third World Factories. Protests by the Third World workers alone, without the First World support, generally have little effect. This point of view, though parochial contains certain truths and is further validated and exemplified by the 2009 and 2010 protests by Shoprite workers in Lagos over poor working conditions and insufficient wages which resulted in their dismissal by the management, coupled with harassment and threats by policemen under the orders of 
the Shoprite management. According to Sahara reporters (2010);

\begin{abstract}
"The workers complained of 'sweat shop' working conditions of service despite record sales. A similar scene had played out in 2009 where the workers' grouse were practically the same. The staff alleged they work long hours, are paid meagre salaries, receive no bonuses, no medical allowance and no annual increments. Acting swiftly, Shoprite sacked the 'rebel' workers replacing them instantaneously though with hitches in its operations. By the time it opened for business last Tuesday it was estimated to have lost about N80 million, a sum which the ex-workers say many times over, outstrips their demands. The aggrieved ex worker's are requesting that the labour union intervene in the matter wondering why an organization should apply zero tolerance by summarily sacking its employees for demanding better working conditions" (Sahara Reporters, 2010).
\end{abstract}

Toyin Cameron of the Nigeria-South Africa Chamber of Commerce (N-SACC), however disagrees with the above assertion. According to her, all countries work by certain policies and laws that regulate their industry and businesses. She stressed that Nigeria's policies are strongly questionable and inconsistent. She contended that under South African legal system, you don't hire and fire people anyhow; there are long legal procedures governing their labour contracts. She argued further that South Africa has one of the most robust labour unions in the world, and as such, the sack of the Nigerian workers in Shoprite saga in 2009 was simply a function of our legal loophole (Cameron, oral interview, 2013).

Furthermore, Perry (2003:3) notes that "while changes in consumer buying habits are often linked to changes in the retail industry, communities are increasingly becoming more aware of both the positive and negative aspects of largescale retail facilities often called "big boxes," "megastores" or "superstores".

The Manufactures Today Report (2013) argues that the presence of foreign and sophisticated retailers will greatly influence the proper modernization of the sector. If indeed, retailing includes all the activities involved in selling goods and services directly to final consumers for their personal, non-business use, then, it simply means that the sector is dominated by the informal sector in Nigeria. This means that while formal retailing holds many benefits for the Nigerian economy, its intensification affects conventional patterns of trading and economic transactions in the country and threatens to displace traditional open markets and means of exchange which accounts for a high percentage of employment and informal labour in the country. In Lagos for instance, according to Abiodun Obisesan (2012), the state government launched a crackdown on illegal roadside trading and partnered with the private sector to construct modern markets. Many of these new facilities have infrastructure such as car parks, water supply, standby electricity and public toilets. Could this portend that traditional market is going extinct?

Furthermore, The Manufacturers Today Report (2013) however adds that, the traditional open markets will continue to exist and thrive because those who would continue to patronize them are in the majority, especially with the prevailing high level of unemployment and poverty; while at the same time and with the existing tendency toward upward social mobility, the middle class will continue to expand thereby promoting the existence and expansion of the formal retail sector which is already being regarded as a status symbol. Invariably, the informal markets will continue to thrive, just as the modern shopping malls continue to spring up in the city centres. This is a clear demonstration of what development economists call "dualism" - the existence of two opposing situations in the same economy (Manufacturers Today Report, 2013).

Moreover, as mentioned at the beginning of this discourse, there are numerous conflicting and sometimes harmonious views held by scholars and researchers on the roles of multinational corporations within the Nigerian society, some of which are relevant and supported by empirical data. For instance, while Loto (2011: 165) and Bakare (2012: 176) conclude that the foreign direct investment variable exerts a positive influence on economic growth, especially in the developing countries as well as serves as a stimulant for economic growth of any country including Nigeria; and that the government of Nigeria has a lot of roles to play in order to maximize the benefit of multinational direct investment, Ozoigbo and Chukuezi (2011:384) disagree and have advanced the view that "MNCs are inherently exploitative, fuelling unemployment, causing structural distortions and contributing to technological backwardness".

In summary, there remains no consensus on the number of foreign megastores presently in Nigeria. The sector is dominated principally by four foreign megastores namely; Shoprite, Spars, Goodies and Park \& Shop. There is also no unanimity in literature or empirical depositions on the role and impact of foreign megastores in and on the Nigerian economy. Indeed, Edward et all (2010:749) argued that most research in the area of retail internationalization has focused on the developed world with little attention being paid to developing economies, especially those in Africa. In view of this, as a consequence, there is limited literature on the influence of foreign megastores on consumption patterns and the health implications of such patterns for citizens as well as how consumer perceptions have determined the successes and failures recorded by foreign megastores. This study is therefore, an attempt to fill this existing gap in 
literature.

\section{Brief History of Foreign Megastores in Nigeria}

As earlier mentioned, multinational corporations have always played important roles in Nigeria even before it became independent in October 1, 1960. According to the Manufactures Today Report (2013), it is well known that nearly all the famous global oil and gas players operate in Nigeria in one way or the other. These companies include Shell, ExxonMobil, ChevronTexaco, Total Fina/Elf (now Total), Conoco, BP, Agip, Eni and Snamprogetti. Nigeria also had many of the global pharmaceutical companies before 1970. Some pulled out and those who remained were indigenized to become fully Nigerian companies such as Pfizer, May \& Baker, and Parke-Davies.

However the history of multinational corporations in Nigeria is rooted in departmental stores owned mainly by Western organizations such as UAC, PZ, UTC, Leventis, SCAO, CFAO, John Holt, Unilever (Lever Brothers), Patterson and Zochonis (PZCussons) among many others.

Also, the socio-political and economic history of Nigeria is best appreciated by first understanding the place of erstwhile Royal Niger Company now referred to as the UAC of Nigeria Plc which is today "the mother company of so many other companies" (Manufacturers Today Report, 2013:13). In fact, UAC boasts of almost over 50 manufacturing and marketing companies which include; Nigerian Breweries, Vitaform, Guinness, Nestle, Glaxo Smithskline, Multilinks, CAP, MTN, Michelin, Warm Spring Waters, Grand Cereals and GM Nigeria to mention a few.

The story of UAC as told by the company reads as follows:

"UAC of Nigeria Plc has a rich and varied history of successful enterprise that pre-dates the geographical entity called Nigeria. The rumps of the company's early days can be traced to the activities of European traders and commercial activities. The company has evolved through a series of mergers and acquisitions and restructurings as the various entrepreneurs sought to enthrone profitable and enduring enterprises. One of the most significant developments in the company's history was the setting up of the Royal Niger Company, which was chartered between 1672 and 1750 to administer the territory that would later become Nigeria. In 1879, the United African Company was found following the merger of four Companies trading up the River Niger: Alexander Miller Brothers \& Company, Central African Trading Company Limited; West African Company Limited and James Pinnock. Following the intense rivalry among the European nations in the 1880s, The National African Company Limited was floated to take over the assets of The United African Company. In 1886, The National African Company Limited was Chartered and Limited when the British government issued it a Charter after the Berlin Conference. In 1889, The African Association was incorporated by the merger of eight firms that were operating in the Oil Rivers area. In 1892, The Royal Niger Company brought in Captain Lugard (later to be known as Lord Lugard) to help protect its interest in Nigeria. Lord Lugard would later become the first Governor-General of Nigeria. Following the revocation of the charter, Royal Niger Company changed its Company name to The Niger Company Limited in 1900. In 1919, The Niger Company Limited was bought by Lever Brothers Limited. That same year, The Miller Brothers Limited and the African Association United merged to form the African \& Eastern Trade Corporation. On March 3, 1929, The United Africa Company was formed by the joint agreements of The African \& Eastern Trade Corporation and the Niger Company (Owned by Lever Brothers Limited). UAC was first incorporated in Lagos, Nigeria under the name Nigerian Motors Ltd on April 22, 1931 as a wholly-owned subsidiary of the United Africa Company Ltd. (a subsidiary of Unilever), which later became UAC International. The Company's name was changed to United Africa Company (Nigeria) Ltd on 23rd July 1943. It became The United Africa Company of Nigeria Ltd on 1st February, 1955 and started acquiring, over a period of five years, a large part of the business of UACI. In 1960, C.W.A. Holdings Ltd, England also a subsidiary of Unilever, acquired UACl's interest in the company. The name was changed to UAC of Nigeria Limited on 1st March, 1973. In compliance with the Nigerian Enterprises Promotion Act 1972, 40 per cent of the company's share capital was acquired in 1974 by Nigerian citizens and associations and in accordance with the provisions of the Nigerian Enterprises Promotion Act 1977, an additional 20 per cent of the UAC's share capital was publicly offered in 1977, increasing Nigerian equity participation to 60 per cent. The name UAC of Nigeria PIC was adopted in 1991. In 1994, following the divestment of 40 per cent interest in the company by Unilever PIc, the company became a wholly-owned Nigerian company. The transformation of UAC from a trading behemoth into a leading manufacturing concern, even though it took root in the 1980s, was given serious impetus in the 1990s, following the exit of the company from its trading businesses. In early 2000, UAC further embarked on a series of business restructuring with a thorough portfolio review and switch of focus to value-adding operations. This has led to an era of focused growth on the foods, real estate, logistics and automobile sectors. UAC has an active foreign investor, Actis, which holds 20 per cent of the company's equity. Today, UAC has become a foodfocused conglomerate with leading brands such as Mr Biggs, Gala, Grand Oils, Supreme, SWAN Natural Spring Water and Gossy Spring Water. The company's brand portfolio also includes franchised international food brands such as Nando's, Creamy Inn, Chicken Inn, Pizza Inn and Dial-A-Delivery". (www.uacnplc.com). 
Unilever is rightly mentioned in the story of UAC and it is important to note that the two companies were together until recently, when unfortunately UAC International had to wound up in London. Perhaps, if not for Chief Ernest Shonekan, the former head of Interim Government (IG) in Nigeria, UAC of Nigeria Plc would not have still been in existence today as a holding company. In fact, UAC appears to be more visible in the Nigerian economy and operating in more sectors than Unilever Nigeria Plc.

On the issue of related party alone, according the company's account:

\begin{abstract}
"Unilever Nigeria PIc principally involved in the manufacture and marketing of foods and food ingredients, home and personal care products is controlled by Unilever PIc incorporated in the United Kingdom, which is the ultimate parent of the Group. There are other companies that are related to Unilever Nigeria PIc through common shareholdings or common directorships. Unilever PIc, London has given Unilever Nigeria PIc exclusive right to the know-how, manufacture, distribution and marketing of its international brands namely: OMO, CLOSE-UP, LIPTION, SUNLIGHT, BLUEBAND, VASELINE, LUX, KNORR, ROYCO, etc. In consideration of this, a Royalty of 3 per cent of Net Sales Value is payable by the company, Unilever PIc London". (www. unilevernigeria.com).
\end{abstract}

Also, PZ Cussons Nigeria Plc, the largest subsidiary of PZ Cussons, has enjoyed tremendous business success in Nigeria for over a century. According to the company,

"No other consumer goods company possesses heritage in Nigeria or understands its customers better than we do. Our approach to Nigeria, our customers, our consumers and to our business is designed to sustain us far into the future. "Our prime business objective in Nigeria is sustainable and profitable growth and our drive to be world-class in every aspect of our business life will be relentless". (www.pzcussons.com).

According to the Manufacturers Today Report (2013), there are many other multinational corporations operating in Nigeria. There would have been a lot more if not for the Nigerian Enterprises Promotion Decrees of 1972 and 1977, and more broadly if not for the process of indigenization in Nigeria which elicited a retreat, especially by the American multinational corporations in the manufacturing sector. It is an example of the negative impact on the process of indigenizing the ownership structure of an economy. Nigeria lost companies like Colgate-Palmolive, Abbot Laboratories and so on.

The nature and evolution of mega stores in Nigeria has thus been heavily influenced by the ruling class and the numerous development policies of governments that Nigeria has experienced. For example, Nigeria under the interim government of Chief Ernest Shonekan who also happened to be the Chairman of the UAC group, witnessed the closure of UACs Kingsway Stores, in an attempt by the government to effectively implement its "import substitution strategy", a policy which though was unsuccessful, was expected to promote the sale and distribution of Nigerian products while at the same time provide jobs for its citizens, reduce dependency and most of all, stimulate industrial growth in the country.

In essence, the above analysis reveals that the phenomenon of foreign megastores in Nigeria is not new to the country's economy and has in fact been heavily intertwined with the country's history. However, in contemporary times, Nigeria has witnessed the proliferation of such megastores which now play a pivotal role which arguably, tilts towards domination and monopolization. This tendency is often orchestrated by the mode of some of their expansion strategy, which is largely based on "wholly-owned entry mode" in the countries where they operate, which allows the company to have absolute control over all its operations, both local and foreign, and managing them from the metropole. Edward et all (2010:750) argued that Shoprite group, operates this mode of expansion and has grown to become the largest food retailer in Africa, as well as the pioneering retailer to embark on a continent wide expansion agenda.

\title{
4. Shoprite and the Nigerian Economy
}

The Shoprite Group of companies came into existence with the acquisition of a supermarket chain in the Western Cape, in 1979 (Shoprite, 2009a). This expansion strategy has continued and has helped the expansion-driven company to show its presence across the country, and the group now comprises Shoprite, Checkers, Checkers Hyper, Usave, OK Furniture, OK House and Home, OK Power Express and OK Franchise Division (with a number of stores and brands under it). The national growth and expansion strategy of Shoprite has been through mergers and acquisitions, but it modified and extended this strategy when moving abroad (Edward et all, 2010).

It achieved international expansion by opening its own stores in the foreign countries in which it operates, so that in 2008, out of a total of 984 stores, 100 supermarkets were operated in 16 countries outside South Africa. These countries include Angola, Botswana, Ghana, Lesotho, Madagascar, Malawi, Mauritius, Mozambique, Namibia, Nigeria, 
Swaziland, Tanzania, Uganda, Zambia, Zimbabwe, and just recently the Democratic Republic of Congo (Shoprite, 2008). The company, with over 1.068 corporate and 275 franchise stores and over 10 million customer base, claims that the international stores operate with the same standards of sophistication obtainable in the home country, South Africa (Chandhuri and Umashankar, 2005; Smith and Smit, 2010: 1). To be sure, the group's operations have been generally successful in most of these countries and in some cases income has exceeded their projections and expectations. Consequently, this performance has triggered numerous growth and expansion plans for most of the countries listed above.

Indeed, Shoprite invested and continues to invest in the human capital of the countries where it operates. The group employs more than 8000 local peoples in its stores outside South Africa, some of whom have been trained to become mangers (Shoprite, 2008). Further, local small scale farmers are being supported to upgrade their production standards so as to supply the Shoprite stores. It has also been reported that the Shoprite Zambian operation is already self-sufficient in vegetable supplies, thanks to the engagement with local farmers (Edward et all, 2010:751).

Shoprite is relatively new to the Nigerian market having spent less than a decade; it has however become a household name. It offers consumers a wide range of imported goods ranging from clothes, electrical appliances, and foodstuff to toiletries, kitchenware and stationeries. It currently has seven functioning outlets in five Nigerian states namely; Lagos, Abuja, Kwara, Enugu and Abia. Its outlets in Kano state and Oyo state are set to open in September and June 2013 respectively. Kayode Oguntuase of the Nigeria High Commission in Pretoria offers an insight into the expansion strategy of Shoprite into the Nigerian market:

"The economy of South Africa is saturated that is why its firms are looking outside for possible prospects... for instance, Shoprite wants to have 300 more new outlets in Nigeria...they have concluded their feasibility studies before arriving at that decision...Nigeria's high purchasing power and the growth of her middle class will sustain that vision..." (Oguntuase, oral interview, 2013)

\subsection{Presentation of Data}

The sample size of the research involved the distribution of 200 questionnaires to a cross section of Nigerians and South Africans who patronise Shoprite stores in Nigeria. A total number of 185 questionnaires were returned representing approximately $90 \%$ retrieval rate. The intention was to test whether there is a relationship between the presence of foreign megastores (represented by Shoprite) and the growth of the Nigerian economy. The following shows the statistical analysis of the sample collected.

Table 4.1.1: Impact of Shoprite on the Nigerian economy

\begin{tabular}{|ll|c|c|c|c|}
\hline & Frequency & Percent & Valid Percent & Cumulative Percent \\
\hline Valid & Strongly Agree & 41 & 22.2 & 22.2 & 22.2 \\
& Agree & 94 & 50.8 & 50.8 & 73.0 \\
& Undecided & 18 & 9.7 & 9.7 & 82.7 \\
Disagree & 27 & 14.6 & 14.6 & 97.3 \\
Strongly Disagree & 5 & 2.7 & 2.7 & 100.0 \\
Total & 185 & 100.0 & 100.0 & \\
\hline
\end{tabular}

Source: Fieldwork (2013)

Interpretation: Table 4.13 above is the respondent's distribution on whether or not Shoprite has positively impacted the Nigerian economy. The table indicates that $22 \%$ of the respondents strongly agree and $51 \%$ also simply agree. $10 \%$ of the respondents were however undecided. Contrarily, 15\% disagree with the statement and 3\% of the respondents strongly disagreed. This analysis indicates that majority of the respondents agreed on the statement that Shoprite has positively impacted the Nigerian economy.

Table 4.1.2: Shoprite's negative impact on the Nigerian economy

\begin{tabular}{|c|c|c|c|c|c|}
\hline & & Frequency & Percent & Valid Percent & Cumulative Percent \\
\hline Valid & Strongly Agree & 36 & 19.5 & 19.5 & 19.5 \\
\hline
\end{tabular}




\begin{tabular}{|l|c|c|c|c|} 
Agree & 48 & 25.9 & 25.9 & 45.4 \\
Undecided & 27 & 14.6 & 14.6 & 60.0 \\
Disagree & 19 & 10.3 & 10.3 & 70.3 \\
Strongly Disagree & 55 & 29.7 & 29.7 & 100.0 \\
Total & 185 & 100.0 & 100.0 & \\
\hline
\end{tabular}

Source: Fieldwork (2013)

Interpretation: On whether or not Shoprite has negatively impacted the Nigerian economy, Table 4.14 above indicates that $20 \%$ of the respondents strongly agree and $26 \%$ also simply agree. $15 \%$ of the respondents were however undecided. Contrarily, 10\% disagree with the statement and $30 \%$ of the respondents strongly disagreed. This analysis indicates that majority of the respondents agreed with the statement that Shoprite has negatively impacted the Nigerian economy.

Table 4.1.3: Shoprite and Reduction of Unemployment in Nigeria

\begin{tabular}{|c|c|c|c|c|c|}
\hline & Frequency & Percent & Valid Percent & Cumulative Percent \\
\hline \multirow[t]{6}{*}{ Valid } & Strongly Agree & 51 & 27.6 & 27.6 & 27.6 \\
\hline & Agree & 73 & 39.5 & 39.5 & 67.0 \\
\hline & Undecided & 30 & 16.2 & 16.2 & 83.2 \\
\hline & Disagree & 16 & 8.6 & 8.6 & 91.9 \\
\hline & Strongly Disagree & 15 & 8.1 & 8.1 & 100.0 \\
\hline & Total & 185 & 100.0 & 100.0 & \\
\hline
\end{tabular}

Source: Fieldwork (2013)

Interpretation: On whether or not Shoprite has contributed to reducing unemployment in Nigeria, Table 4.15 above indicates that $28 \%$ of the respondents strongly agree and $40 \%$ simply agree. $16 \%$ of the respondents were however undecided. Contrarily, $9 \%$ disagree with the statement and $8 \%$ of the respondents strongly disagreed. This analysis indicates that majority of the respondents agreed with the statement that Shoprite has contributed to reducing unemployment in Nigeria.

Table 4.1.4: Shoprite and Exploitation of Cheap Labour in Nigeria

\begin{tabular}{|c|c|c|c|c|c|}
\hline & Frequency & Percent & Valid Percent & Cumulative Percent \\
\hline \multirow[t]{6}{*}{ Valid } & Strongly Agree & 50 & 27.0 & 27.0 & 27.0 \\
\hline & Agree & 50 & 27.0 & 27.0 & 54.1 \\
\hline & Undecided & 54 & 29.2 & 29.2 & 83.2 \\
\hline & Disagree & 15 & 8.1 & 8.1 & 91.4 \\
\hline & Strongly Disagree & 16 & 8.6 & 8.6 & 100.0 \\
\hline & Total & 185 & 100.0 & 100.0 & \\
\hline
\end{tabular}

Source: Fieldwork (2013)

Interpretation: Respondents were asked whether or not Shoprite exploits cheap labour in Nigeria. Table 4.16 above indicates that $27 \%$ of the respondents strongly agree and $27 \%$ simply agree. $29 \%$ of the respondents were however undecided. Contrarily, $8 \%$ disagree with the statement and $9 \%$ of the respondents strongly disagreed. This analysis indicates that majority of the respondents agreed with the statement that Shoprite exploits cheap labour in Nigeria.

Table 4.1.5: The Quality of Goods in Shoprite and the Traditional Open Markets.

\begin{tabular}{|ll|c|c|c|c|}
\hline & & Frequency & Percent & Valid Percent & Cumulative Percent \\
\hline Valid & Strongly Agree & 29 & 15.7 & 15.7 & 15.7 \\
& Agree & 63 & 34.1 & 34.1 & 49.7
\end{tabular}




\begin{tabular}{|l|c|c|c|c|} 
Undecided & 32 & 17.3 & 17.3 & 67.0 \\
Disagree & 35 & 18.9 & 18.9 & 85.9 \\
Strongly Disagree & 26 & 14.1 & 14.1 & 100.0 \\
\hline Total & 185 & 100.0 & 100.0 & \\
\hline
\end{tabular}

Source: Fieldwork (2013)

Interpretation: Table 4.18 above is a frequency distribution of respondents on whether or not goods found in Shoprite are of better quality than those in traditional open markets. The table indicates that $16 \%$ of the respondents strongly agree and $34 \%$ simply agree. $17 \%$ of the respondents were however undecided. Contrarily, $19 \%$ disagree with the statement and $14 \%$ of the respondents strongly disagreed. This analysis indicates that majority of the respondents agreed with the statement that labour unions and security forces encourage exploitation of workers by foreign megastores.

Table 4.1.6: Shoprite and Promotion of Chemically Treated Foods.

\begin{tabular}{|c|c|c|c|c|c|}
\hline & & Frequency & Percent & Valid Percent & Cumulative Percent \\
\hline Valid & $\begin{array}{l}\text { Strongly Agree } \\
\text { Agree } \\
\text { Undecided } \\
\text { Disagree } \\
\text { Strongly Disagree } \\
\text { Total }\end{array}$ & $\begin{array}{c}18 \\
55 \\
48 \\
45 \\
19 \\
185\end{array}$ & $\begin{array}{c}9.7 \\
29.7 \\
25.9 \\
24.3 \\
10.3 \\
100.0\end{array}$ & $\begin{array}{c}9.7 \\
29.7 \\
25.9 \\
24.3 \\
10.3 \\
100.0\end{array}$ & $\begin{array}{c}9.7 \\
39.5 \\
65.4 \\
89.7 \\
100.0\end{array}$ \\
\hline
\end{tabular}

Source: Fieldwork (2013)

Interpretation: The table above shows the frequency distribution of respondents on whether or not Shoprite promotes chemically treated food over naturally grown food. The table indicates that $10 \%$ of the respondents strongly agree and $30 \%$ simply agree. $26 \%$ of the respondents were however undecided. Contrarily, $24 \%$ disagree with the statement and $10 \%$ of the respondents strongly disagreed. This analysis indicates that majority of the respondents agreed with the statement that Shoprite promotes chemically treated food over naturally grown food.

Table 4.1.7: Shoprite attracts only high and middle income earners.

\begin{tabular}{|c|c|c|c|c|c|}
\hline & & Frequency & Percent & Valid Percent & Cumulative Percent \\
\hline \multirow[t]{6}{*}{ Valid } & Strongly Agree & 48 & 25.9 & 25.9 & 25.9 \\
\hline & Agree & 60 & 32.4 & 32.4 & 58.4 \\
\hline & Undecided & 14 & 7.6 & 7.6 & 65.9 \\
\hline & Disagree & 39 & 21.1 & 21.1 & 87.0 \\
\hline & Strongly Disagree & 24 & 13.0 & 13.0 & 100.0 \\
\hline & Total & 185 & 100.0 & 100.0 & \\
\hline
\end{tabular}

Source: Fieldwork (2013)

Interpretation: Table 4.20 above is a frequency distribution of respondents on whether or not Shoprite attracts only high and middle income earners. The table indicates that $26 \%$ of the respondents strongly agree and $32 \%$ simply agree. $8 \%$ of the respondents were however undecided. Contrarily, $21 \%$ disagree with the statement and $13 \%$ of the respondents strongly disagreed. This analysis indicates that majority of the respondents agreed with the statement that Shoprite attracts only high and middle income earners.

Table 4.1.8: Shoprite Charges and the worth of the services rendered.

\begin{tabular}{|c|c|c|c|c|}
\hline & Frequency & Percent & Valid Percent & Cumulative Percent \\
\hline Valid Strol & 41 & 22.2 & 22.2 & 22.2 \\
\hline
\end{tabular}




\begin{tabular}{|l|c|c|c|c|} 
Agree & 94 & 50.8 & 50.8 & 73.0 \\
Undecided & 20 & 10.8 & 10.8 & 83.8 \\
Disagree & 25 & 13.5 & 13.5 & 97.3 \\
Strongly Disagree & 5 & 2.7 & 2.7 & 100.0 \\
Total & 185 & 100.0 & 100.0 & \\
\hline
\end{tabular}

Source: Fieldwork (2013)

Interpretation: The table above is a frequency distribution of respondents on whether or not the amount paid at Shoprite is worth the services rendered. The table indicates that $22 \%$ of the respondents strongly agree and $51 \%$ simply agree. $11 \%$ of the respondents were however undecided. Contrarily, $14 \%$ disagree with the statement and $3 \%$ of the respondents strongly disagreed. This analysis indicates that majority of the respondents agreed with the statement that the amount paid at Shoprite is worth the services rendered.

Table 4.1.9: Choice of Supermarket: foreign megastore or indigenous supermarket

\begin{tabular}{|cc|c|c|c|c|}
\hline & & Frequency & Percent & Valid Percent & Cumulative Percent \\
\hline Valid & Yes & 97 & 52.4 & 52.4 & 52.4 \\
& No & 88 & 47.6 & 47.6 & 100.0 \\
& Total & 185 & 100.0 & 100.0 & \\
\hline
\end{tabular}

Source: Fieldwork (2013)

Interpretation: Respondents were asked whether they would rather shop in foreign megastore than in an indigenous supermarket. Table 4.25 above indicates that $52 \%$ of the respondents agreed while $48 \%$ disagreed. This analysis indicates that more of the respondents would prefer to shop in foreign megastore than in an indigenous supermarket.

Table 4.1.10: Reason for the choice of shopping Centre

\begin{tabular}{|cl|c|c|c|c|}
\hline & & Frequency & Percent & Valid Percent & Cumulative Percent \\
\hline Valid & Convenience & 80 & 43.2 & 43.2 & 43.2 \\
& Price & 100 & 54.1 & 54.1 & 97.3 \\
& Hygiene & 1 & .5 & .5 & 97.8 \\
Quality & 4 & 2.2 & 2.2 & 100.0 \\
Total & 185 & 100.0 & 100.0 & \\
\hline
\end{tabular}

Source: Fieldwork (2013)

Interpretation: Respondents were asked why they would choose to shop in foreign megastore than in an indigenous supermarket. $43 \%$ indicated that their choice is because of convenience while $54 \%$ indicated that it is because of price. $5 \%$ indicated hygiene as the reason for their choice while $2 \%$ noted it is because of quality. This analysis indicates that majority of the respondents preferred shopping in foreign megastore than in an indigenous supermarket.

\subsection{Test Result of Hypotheses}

Ho: That there is no relationship between the presence of foreign mega stores and the growth of the Nigerian economy.

$\mathrm{Hr}$ : That there is a relationship between the presence of foreign mega stores and the growth of the Nigerian economy.

Variables Entered/Removed (b)

\begin{tabular}{|l|l|l|l|}
\hline Model & \multicolumn{1}{|c|}{ Variables Entered } & Variables Removed & Method \\
\hline 1 & $\begin{array}{l}\text { Positive impact } \\
\text { Reduce unemployment } \\
\text { Quality products (a) }\end{array}$ &. & Enter \\
\hline
\end{tabular}

a All requested variables entered. 
b Dependent Variable: foreign megastores

Model Summary

a. Predictors: (Constant), Positive impact

\begin{tabular}{|c|c|c|c|c|}
\hline Model & R & R Square & Adjusted R Square & Std. Error of the Estimate \\
\hline 1 & $.318(\mathrm{a})$ & .101 & .086 & 1.46231 \\
\hline
\end{tabular}

Reduce unemployment

Quality products

ANOVA(b)

\begin{tabular}{|cc|c|c|c|c|c|}
\hline Model & & Sum of Squares & Df & Mean Square & $F$ & Sig. \\
\hline 1 & Regression & 43.523 & 3 & 14.508 & 6.785 & $.000(\mathrm{a})$ \\
& Residual & 387.039 & 181 & 2.138 & & \\
& Total & 430.562 & 184 & & & \\
\hline
\end{tabular}

a. Predictors: (Constant), Positive impact

Reduce unemployment

Quality products

b. Dependent Variable: foreign megastores

Coefficients (a)

\begin{tabular}{|cl|c|c|c|c|c|}
\hline Model & \multicolumn{2}{|c|}{ Unstandardized Coefficients } & Standardized Coefficients & t & Sig. \\
\hline & & B & Std. Error & Beta & B & Std. Error \\
\hline 1 & (Constant) & 3.510 & .315 & & 11.133 & .000 \\
& Positive impact & -.439 & .119 & -.300 & -3.685 & .000 \\
& Reduce unemployment & .022 & .103 & .017 & .215 & .830 \\
& Quality products & .230 & .088 & .187 & 2.607 & .010 \\
\hline
\end{tabular}

a. Dependent Variable: foreign megastores

The result of the regression test as shown in the ANOVA table above indicates an F-cal value of 6.785 at the associated significant level of 0.000 .

Decision: By the statistical rule a hypothesis is rejected when the level of significant is less than 0.05 or accepted when it is more than 0.05 . Since the ANOVA test showed a level of significance of 0.000 which is less than the conventional significant level, the null hypothesis that there is no relationship between the presence of foreign mega stores and the growth of the Nigerian economy is rejected. We therefore accept the alternative hypothesis which states that there is a relationship between the presence of foreign mega stores and the growth of the Nigerian economy.

\subsection{Discussion of Findings}

The Nigerian economy, in recent years continues to witness the emergence and intensification of organized retail outlets (.i.e. supermarkets), most of which are foreign and private-owned, as opposed to the traditional open markets. Investigation shows that there is a relationship between government policies and the intensification of these foreign megastores in Nigeria. The development of these foreign megastores, particularly, Shoprite - a South African megastore operating in Nigeria is however not without positive and negative implications on the socio-economic and political development of the country. Findings of this research show that there is a relationship between the presence of these foreign mega stores particularly, Shoprite and the growth of the Nigerian economy. Investigation reveals that Shoprite has contributed to reducing unemployment in Nigeria. Our interview with Julius Nwakuala, the Administrative Manager of Shoprite reveals that the six stores owned by Shoprite have been able to provide 1500 Nigerian youths with employment. In addition, Shoprite provides better quality goods than those in traditional open markets. Goods at Shoprite are always of high quality especially the edibles and perishable goods. According to the Administrative Manager:

That's one of the standards of Shoprite from inception; we have continued to do that with critical examination, in every store we have groups that every day check the fresh fruits and the standards. We have been able to improve on our qualities of fresh foods, so that is what we do because it is easier for people to get diseases through food and other things, so that is why we are critical about maintaining quality standard of our goods (Shoprite Admin Manager, oral interview, 2013). 
The quality of the products found in Shoprite was also corroborated by the General Secretary of Nigerian Union of Shop and Distributive Employees (N.U.S.D.E), Comrade Sule Babatunde. Our interview with him reveals that foreign megastores, particularly, Shoprite has one basic reputation and that is quality products

One of the negative impacts of Shoprite on the Nigeria economy however, is the fact that it exploits cheap labour in Nigeria. Findings revealed that labour unions and security forces encourage exploitation of workers by foreign megastores. In addition, Shoprite promotes foreign and South African products over indigenous Nigerian products, although this was denied by the Administrative Manger of Shoprite who argued that goods at Shoprite are in the ration $60 / 40$. According to him "forty for imported, sixty for local products and with the way we are going, with time, it is going to increase. It could become 30/70 in the nearest future." (Oral interview, 2013). Findings also revealed that Shoprite promotes chemically treated food over naturally grown food and these are foreign products, particularly from South Africa.

Furthermore, findings show that the presence of foreign megastores threatens the existence of traditional open markets and indigenous supermarkets. According to Mr. Michael Azim, the Manager of DePrince supermarket, while foreign megastores have access to fund which is very pivotal to the business of retail chain outlet in Nigeria, the indigenous firms find it difficult to source for loans for expansion or for branch network. The foreign mega stores have access to finance which the indigenous firms do not have; their expansion thus, constitute a threat to the indigenous supermarkets. It is in the light of this that Blessing Nwezu, the Supervisor of Royal Priesthood supermarket argued that, improving the capacity of microfinance banks in Nigeria to grant soft loans to local firms will help position the indigenous business organizations to withstand the competitive environment being promoted by foreign megastores.

Another basic finding of this research is that there is a relationship between consumer perceptions and the displacement of traditional markets in Nigeria. Consumer's perception of high quality products from foreign megastores, perception of class, i.e., that such supermarkets belong to high and middle income earners, perception of convenience, safety, taste and hygiene. Findings revealed that this image portrayed by foreign megastores particularly, Shoprite influences customers buying habits against the traditional open market.

\section{Conclusion}

In this paper, the presence of foreign megastores in Nigeria and what it portends for Nigeria's economy and consumption pattern has been examined. While the presence of formal retailing which Shoprite represents are central to solving economic and social problems in Nigeria, the intensification of such multinational companies is not without some costs on the socio-economic and political life of the country. Indeed, their presence has adversely affected indigenous markets through their use of more sophisticated facilities, better packages and more improved and innovative services. The larger implication of all these does not only portend future threats to the indigenous market structure on which Nigeria's informal sector relies, but may radically restructure the labour relations in the country. To this effect, the study canvasses a critical review of the government's policies governing the operations of these megastores with a view to enhancing the growth of local retail outlets which will inevitably promote the growth of the local economy.

\section{References}

Agbu, O. (2004), 'Globalisation and International Terrorism: The Challenges for Nigeria's Foreign Policy', in B.A Akinterinwa (ed), Nigeria's New Foreign Policy Thrust: Essays in Honour of Ambassador Oluyemi Adeniji, Vantage Publishers, Ibadan, pp. 32

Aina, .A.D. (2006). Globalization and the Challenges of National Development: The Ayanwole, Adeolu (2007). FDI and Economic Growth: Evidence from Nigeria.

Bakare, .A.S. (2010). "Multinational Direct Investment and Economic Growth in: Begg, David, Stanley Fischer \& Rudiger Dornbusch. (2008). Economics. UK:

Business and Economy (2012) "Foreign Investment in Retail Sector hits all-time Case of Post Debt Relief in Nigeria retrieved on 19th January 2012 from www. Unionbankng.com/Ayandiji.pdf.

Chandhuri, .S. \& Umashankar, .R. (2005). "Shoprite: South African Retailer's Company Inc.

Conversi, D. (2010) "The Limits of Cultural Globalization?", Journal of Critical Globalization Studies, Issue 3, pp. 36-59. Direct Foreign Investment: The Nexus between/among them and their Roles in the Underdevelopment of the Third World. Abuja: DPA. Economic Development: The Nigerian Experience", Journal of Social Sciences, Vol. 14, No. 1, Pg 45-51. Expanding Influence" retrieved on 14th January, 2013 from www.brandinteligence.com. Experience and Prospects, 1980-2008", Journal of Emerging Trends in Economics and Management Sciences, Vol 2, No. 3, Pg 160-167.

Goldstein, J.S. and Pevehouse, J.C. (2011). International Relations. USA: Longman Growth Strategies". South Africa: AABS. High" retrieved on 20th January, 2013 from www.nairaland.com. Labour Conditions of Developing Countries: The Nigerian Experience", 
European Journal of Business and Social Sciences, Vol 1, No. 6, Pg 67-76.

Loto, M.A. (2011). "Globalization and Economic Development: The Nigerian Manufacturers Today Report. (2013). "Retailing: The End of the Value Chain" McGraw-Hill.

Mingst, .K. (1999). Essentials of International Relations. USA: W. W. Norton \&

Movius, L. (2010) "Cultural Globalisation and Challenges of Traditional Communication Theories", PLATFORM: Journal of Media and Communication, Vol.2, No.1, pp. 6-18. Nairobi: African Economic Research Consortium. Nigeria: An Empirical Study", International Business Management, Vol 4, No. 3, Pg 171-176.

Obisesan, .A. (2012). "Mega Retail Stores: Can Traditional Market Stand Their

Omotola, J. S. (2010) "Globalization, New Regionalism and the Challenge of Development in Africa", Africana on the Nigerian Economy", European Journal of Social Sciences, Vol 19, No. 3, Pg 380-387.

Onodugo, .V.A. (2012). "Multinational Corporations (MNC) and Employment and

Onwuka, Emmanuel Chike and Eguavoen, Agatha (2007). "Globalisation and

Oyadiran, .P. \& Akintola, O.E (2003). Globalisation, Multinational Corporations and

Ozoigbo. B.I. \& Chukuezi . C.O. (2011). "The Impact of Multinational Corporations Pearson.

Perry, T.L. (2001). "Big Box" Retail Development. USA: Maryland Department of Planning. retrieved on $14^{\text {th }}$ January, 2013 from www.maufacturerstodaynigeria.com.

Salmon, T.C. and Imber, M.F. (2008) (eds) Issues in International Relations. New

Smith, .A. \& Smit, .H. (2010). "Case Study: Shoprite". South Africa: CENFRI.York: Routledge. 
